\title{
Risk Analysis Of Hedge Funds: A Markov Switching Model Analysis
}

\author{
Frédéric Teulon, IPAG Business School - IPAG Research Lab - Paris, France \\ Khaled Guesmi, IPAG Business School - IPAG Research Lab - Paris, EconomiX-CBRS, \\ University of Paris Ouest Nanterre la Défense, France \\ Saoussen Jebri, EconomiX-CNRS, University of Paris Ouest Nanterre la Défense, France
}

\begin{abstract}
The paper applies Markov Regime Switching GARCH Model (SW-GARCH) to investigate the volatility behavior of strategies hedge fund monthly returns for the period 1997-2011. The results highlight two different regimes: The first regime is characterized by a high volatility for all strategies hedge fund monthly returns. The second is characterised by lower volatility and positive average returns (except Emerging Market strategy). Our results helped to capture even the shortlived crises along with the material crises of 2001 and 2008.
\end{abstract}

Keywords: Markov Regime Switching; Conditional Volatility; Hedge Fund

\section{INTRODUCTION}

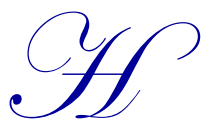

edge funds occupy nowadays an important role in international finance, they often appear as actors who act in the shadows. The literature on hedge funds has grown in four directions: 1) performance, 2) composition of asset portfolios, 3) the executive compensation; 4) their exposure and their regulation.

Issues related to risk and performances are privileged here. It is not always easy to evaluate the systematic risk exposures of the hedge funds, especially those using buy-and-hold and option-based strategies (Agarwal \& Naik, 2004). Different specific performance measures have been suggested for hedge funds, even though some question the usefulness (Eling \& Schumacher, 2007).

Hedge funds exhibit return properties that are specific. First of all, the returns are non-normally distributed. Second, hedge funds might change the strategies over time and their exposure to risk factors might be highly dynamic (Fung \& Hsieh, 1997). Third, hedge funds returns are not linearly related to global stock exchange index or risk factors (Fung \& Hsieh, 1997; Fung \& Hsieh, 2011).

Table 1: Hedge Funds Strategies

\begin{tabular}{lll}
\hline $\begin{array}{l}\text { Market Trend (Directional/Tactical) } \\
\text { Strategies - Panel A }\end{array}$ & \multicolumn{1}{c}{ Arbitrage Strategies - Panel B } & Event Driven Strategies - Panel C \\
\hline $\begin{array}{l}\text { These strategies exploit broad market } \\
\text { trends in equities, interest rates or }\end{array}$ & $\begin{array}{l}\text { These strategies exploit pricing } \\
\text { discrepancies between closely related } \\
\text { commodity prices. }\end{array}$ & $\begin{array}{l}\text { These strategies attempt to exploit } \\
\text { discrete events such as bankruptcies, } \\
\text { mergers, and takeovers. }\end{array}$ \\
\hline \begin{tabular}{l} 
Source: SEC, "Implications of the growth of hedge funds", September 2003. \\
\hline
\end{tabular}
\end{tabular}

The aim of this paper is to analyze the nonlinear behavior of hedge funds returns during financial crises. Many authors have argued that nonlinear processes model better the behavior of different financial variables than the linear ones. In particular, Markov regime-switching models have been shown to properly capture the dynamics of several financial assets data series which occasionally exhibit periodical breaks in their behavior associated with events such as financial crises or abrupt changes in government policy. For example, many financial assets present an apparent tendency to behave quite differently during economic downturns due to the sudden changes in fundamentals (e.g. Ang \& Bekaert, 2002; Garcia et al., 2003; Dai et al., 2003). On the other hand, Markov regime- 
switching models possess other appealing features since they can better capture fat tails, asymmetries, autocorrelation, volatility clustering or mean reversion in financial asset series. Building on the seminal work of Hamilton (1989) regime-switching methods have been widely used in a variety of contexts: to model stock market returns (e.g. Hamilton \& Susmel, 1994; Gray, 1996; Chauvet \& Potter, 2000; Ang \& Bekaert, 2002; Ang \& Chen, 2002), commodities prices (e.g. de Jong, 2006; Chen \& Forsyth, 2010), exchange rates dynamics (e.g. Engel \& Hamilton, 1990; Engel, 1994; Dacco \& Satchell, 1999; Bollen et al., 2000), etc.

Our paper contributes to the published research in two ways. First the present study contributes to the literature by developing a Markov regime-switching model. Second, this paper provides a comprehensive evaluation of hedge fund performance and risk.

The rest of the article is organized as follows: Section 2 presents the methodology used. Section 3 describes the data. Section 4 presents the estimation results. Section 5 discusses the results. Section 6 draws the appropriate conclusions.

\section{MODEL AND METHODOLOGY}

This empirical part adopts Markov Regime Switching GARCH models to estimate the volatility of the strategies hedge fund returns. The use of GARCH model and its various variants have become the standard for studying and analysing time varying conditional volatility where the conditional means and variances of GARCH models are fixed for the entire sample period. Hamilton and Susmel (1994) and Cai (1994) suggest a regimeswitching model with ARCH innovations in which they allow the conditional variance to switch among different regimes according to a latent state variable that follows a Markov process. Gray (1996) proposed a generalized regime-switching model, which may be described as follows:

$$
\begin{aligned}
& r_{t}=\mu\left(S_{t}\right)+\varepsilon_{t} \\
& \varepsilon_{t} \rightarrow \varepsilon_{t} \sqrt{h_{t}\left(S_{t}\right)} \\
& h_{t}\left(S_{t}\right)=\alpha_{0}\left(S_{t}\right)+\alpha_{1} \varepsilon_{t-1}^{2}+\beta_{1}\left(S_{t}\right) h_{t-1}
\end{aligned}
$$

where $r_{t}, S_{t}, \mu\left(S_{t}\right)$ and $h_{t}\left(S_{t}\right)$ are the return at time t, conditional mean and conditional variances respectively. Both are allowed to switch between two regimes. To confirm positivity of conditional variance in each regime, indispensible conditions are similar to the necessary conditions in uni-regime GARCH $(1,1)$ model. The unobserved regime variable $S_{t}$ is governed by a first order Markov Chain with constant transition probabilities given by:

$$
\begin{aligned}
& \operatorname{Pr}\left(S_{t}=0 / S_{t-1}=0\right)=P_{00} \\
& \operatorname{Pr}\left(S_{t}=1 / S_{t-1}=1\right)=P_{11} \\
& \operatorname{Pr}\left(S_{t}=0 / S_{t-1}=1\right)=P_{10}=1-P_{11} \\
& \operatorname{Pr}\left(S_{t}=1 / S_{t-1}=0\right)=P_{01}=1-P_{00}
\end{aligned}
$$

In matrix notation,

$$
P=\left[\begin{array}{cc}
P_{00} & 1-P_{11} \\
1-P_{00} & P_{11}
\end{array}\right]
$$

Then, conditional distribution of return series $r_{t}$ becomes a mixture of distribution model in which mixing variable is ex-ante probability $\operatorname{Pr}\left(S_{t}=i / \pi_{t-1}\right)$ denoted by $P_{i t}$, 
$r_{t} / \pi_{t-1}=\left\{\begin{array}{l}f\left(r_{t} / S_{t}=0, \pi_{t-1}\right) \text { with probability } p_{0 t} \\ f\left(r_{t} / S_{t}=1, \pi_{t-1}\right) \text { with probability } p_{1 t}=1-p_{0 t}\end{array}\right.$

where $f\left(r_{t} / S_{t}=1, \pi_{t-1}\right)$ denotes one of the assumed conditional distributions for errors: Normal, Student-t or GED. $\pi_{t-1}$ denotes the information at time t-1. $p_{0 t}$ is the ex-ante probability of being in regime 0 . The loglikelihood function for SW-GARCH model can be written as:

$L=\sum_{t=1}^{T} \ln \left[\sum_{S_{t}=1}^{2} f\left(r_{t} / S_{t}=1, \pi_{t-1}\right) \operatorname{Pr}\left(S_{t} / \pi_{t-1}\right)\right]=\sum_{t=1}^{T} \ln \left[f\left(r_{t} / S_{t}=0, \pi_{t-1}\right) p_{0 t}+f\left(r_{t} / S_{t}=1, \pi_{t-1}\right) p_{1 t}\right]$

The $\operatorname{Pr}\left(S_{t} / \pi_{t-1}\right)$ is the regime probability at time $t$ based on the all information up to time $\mathrm{t}-1$. Both Hamilton and Susmel (1994) and Cai (1994) limited their estimation to the Markov Regime Switching ARCH model. The reason is that there is an infinite path dependence problem inherent in SW-GARCH models.

In SW-ARCH models, the conditional variance at time $\mathrm{t}$ depends on past $q$ squared residuals and past $q$ regime variables $\left(S_{t}, . ., S_{t-q}\right)$. However, in SW-GARCH model, the conditional variance at time $t$ depends on the conditional variance at time $\mathrm{t}-1$ and regime variable $\left(S_{t}\right)$ at time t. While the conditional variance at time $\mathrm{t}-1$ depends on the conditional variance at time $\mathrm{t}-2$ and regime variable $\left(S_{t-1}\right)$ at time $\mathrm{t}-1$, and so on. Therefore, the conditional variance at time $t$ depends on the entire history of regimes up to time t. Both Hamilton and Susmel (1994) and Cai (1994) indicated that path dependence nature of SW-GARCH model makes estimation impossible for large sample size. In order to resolve problem of path dependence in SW-GARCH model, Gray (1996) proposed to use conditional expectation of the lagged conditional variance $E_{t-2}\left(h_{t-1}\right)$ instead of lagged conditional variance $h_{t-1}$. This approach preserves the natural essential of the GARCH process and allows tractable estimation of model. Gray's approach recombines $h_{t-1}\left(S_{t-1}\right)=0$ and $h_{t-1}\left(S_{t-1}\right)=1$ into $h_{t-1}$, and recombines $\varepsilon_{t-1}\left(S_{t-1}\right)=0$ and $\varepsilon_{t-1}\left(S_{t-1}\right)=1$ into $\varepsilon_{t-1}$ by taking conditional expectations of $h_{t-1}$ and $\varepsilon_{t-1}$ based on the ex-ante probabilities. That is,

$$
\begin{aligned}
& h_{t-1}=E_{t-1}\left(h_{t-1}\right) \\
& =E_{t-1}\left(r_{t-1}^{2} / \pi_{t-2}\right)-\left[E_{t-1}\left(r_{t-1} / \pi_{t-2}\right)\right]^{2} \\
& =p_{1 t-1}\left[\varepsilon^{2}\left(S_{t-1}=0\right)+h_{t-1}\left(S_{t-1}=0\right)\right]\left(1-p_{1 t-1}\right)\left[\varepsilon^{2}\left(S_{t-1}=1\right)+h_{t-1}\left(S_{t-1}=1\right)\right]
\end{aligned}
$$

Similarly, error terms $\varepsilon_{t-1}$ is given by:

$\varepsilon_{t-1}=r_{t-1}-E\left(r_{t-1} / \pi_{t-2}\right)=r_{t-1}-p_{1 t-1} \varepsilon\left(S_{t-1}=0\right)+\left(1-p_{1 t-1}\right) \varepsilon\left(S_{t-1}=1\right)$

The conditional variance $h_{t}\left(S_{t}\right)$ in Gray's model can be written as:

$h_{t}\left(S_{t}\right)=\alpha_{0}\left(S_{t}\right)+\alpha_{1}\left(S_{t}\right) \varepsilon_{t-1}^{2}+\beta_{1}\left(S_{t}\right) h_{t-1}$ 
The procedure of conditional expectation of the lagged conditional variance $E_{t-2}\left(h_{t-1}\right)$ instead of lagged conditional variance $h_{t-1}$ makes conditional variance at time t depends on only current regime $S_{t}$ and inference about $S_{t-1}$. Therefore, the Gray's collapsing procedure simplifies and makes tractable the estimation of SW-GARCH models. Given initial values for regime probabilities, conditional mean and variance in each regime, the parameters of SW-GARCH model can be estimated by maximizing numerically the log-likelihood function known in equation (8).

\section{DATA}

The data is obtained from Hedge Fund Research Inc. (hereafter HFR), one of the largest hedge fund databases available for academic research. We selected nine indices hedge funds extracted from this database. This choice is explained by the fact that these indices are the best known and most often used in empirical studies. In addition, these indices have a long enough history that provides some robustness calculations on time series. For completeness, we also study an asset-weighted portfolio comprising the whole hedge fund industry (Fund of Funds).

The hedge fund returns analyzed have been calculated from the indices expressed in US dollars. Data are monthly and span the period March 1997 to December 2011. The investment strategies are presented in Table 1. We apply this study to ten index hedge fund monthly returns (see Figure 1) representing these investment strategies and covering the period:

\section{Market Trend (Directional/Tactical) Index}

- Global Macro (GM) aim to profit from changes in global economies as influenced by major economic trends and/or events. They use leverage and derivatives to accentuate the impact of market moves. In consequence their expected volatilities are very high.

- $\quad$ Emerging Market (EM) invests in equity or debt of emerging markets. There are no viable futures or other derivative products for hedging. Emerging market hedge funds can be partially hedge via U.S. treasury futures and currency markets, but their expected volatility is very high.

- Dedicated Short Bias (DSB) hedge funds are specialized in the short sale of over-valued securities. Because losses on short-only positions are theoretically unlimited (because the stock can rise indefinitely), these strategies are particularly risky.

- $\quad$ Equity Hedge Strategies (EH) maintain positions in primarily equity and equity derivative securities. Equity Hedge managers would typically maintain at least 50 percent exposure to, and may in some cases be entirely invested in, equities - both long and short. Managers try to identify overvalued stocks to sell short.

\section{Arbitrage Index}

- $\quad$ Equity Market Neutral (EMN) tends to negate the impact and risk of general market movement. There are two principal sub-categories: Market neutral Arbitrage (attempts to hedge out most market risk by taking offsetting positions) and Market Neutral Securities Hedging (invests equally in long and short equity portfolios generally in the same sectors of the market). Due to the deep level of exposure to the stock market, the expected volatility is generally low.

- $\quad$ Convertible Arbitrage (CA) entail buying a corporate convertible bond, while simultaneously selling short the common stock of the same company that issued the bond. Arbitrageurs seek to take advantage of anomalies that can appear between the price of a bond convertible into shares and the price of these shares. The idea is to make money from the bond's yield if the bond goes up but also make money from the short sale if the stock goes down. As the convertible bond and the stock can move independently, this investment is very risky. The expected volatility is then high. 


\section{Event Driven Index}

- $\quad$ Event-driven (ED) focus on price movements observed during anticipation of corporate event such as leveraged buy-outs, mergers and hostile takeovers. The most common event driven strategies are distressed securities and merger arbitrage.

- Merger arbitrage strategies (MA) focus primarily on opportunities in equity and equity related instruments of companies which are currently engaged in a corporate transaction. Merger arbitrage strategies typically have over $75 \%$ of positions in announced transactions over a given market cycle.

- Multi-Strategies (MS) are typically quantitatively driven and seek to identify attractive positions that exploit spreads involving combinations of fixed income, derivative, equity, real estate and other instruments. Managers invest in several hedge fund strategies promoting diversification of risk. These strategies are expected to maintain more than $30 \%$ of portfolio exposure in two or more distinct strategies.

\section{Fund of Funds Index}

- $\quad$ Fund of Funds (FoF) mixes and matches hedge funds. This blending of different strategies and asset classes aims to provide a high level of diversification and a more stable long-term investment return than any of the individual funds. Returns, risk, and volatility can be controlled by the mix of underlying strategies and funds.

\section{RESULTS}

Several authors such as Wang and Theobald (2008) stressed that the identification of regime change is difficult, as the search for the number of regimes cannot be observed through the use of simple Wald ratio and the test of likelihood ratio. To resolve this problem, we have applied the likely hood ratio test developed by Garcia and Perron (1996) to verify the existence of regime change for each market under study.

Table 2: Likelihood Ratio

\begin{tabular}{llcc}
\hline & $\ln L_{\text {GARCH }(1,1)}$ & $\ln L_{M S-G A R C H(1,1)}$ & Test LR \\
\hline Panel A & & & $-268,06$ \\
\hline Global Macro & $-2296,23$ & $-2028,17$ & $-22,98$ \\
Emerging Markets & $-2031,19$ & $-2008,21$ & $-29,91$ \\
Short Bias & $-2075,13$ & $-2045,22$ & 62,95 \\
Equity Hedge & $-2102,16$ & $-2165,11$ & $-139,86$ \\
\hline Panel B & & $-2142,25$ & $-117,9$ \\
\hline Equity Market Neutral & $-2282,11$ & $-29,41$ \\
Convertible Arbitrage & $-2192,15$ & $-2321,15$ & \\
Multi- Strategy & $-2350,56$ & & $-321,45$ \\
\hline Panel C & & $-2082,66$ & $-247,62$ \\
\hline Event Driven & $-2404,11$ & $-2004,52$ & 70,14 \\
Merger Arbitrage & $-2252,14$ & $-2078,28$ & $-321,45$ \\
\hline Fund of Funds & $-2008,14$ & $-2082,66$ & \\
\hline SP500 & $-2404,11$ & & \\
\hline
\end{tabular}

Note: +++ indicate the null hypothesis of no regime switching volatility is rejected at the $1 \%$ level.

However, we test the null hypothesis of no regime change for the hedge funds returns represented by the GARCH $(1,1)$ model with a single regime against the Markov Regime Switching (MS-GARCH $(1,1)$ ) specification, which implies the existence of more than one regime for each hedge funds index under study. We start by determining the number of delays with the help of autoregressive model by applying the Akaike Information Criteria (1974) and of Hannan and Quinn (1979). The LR test is defined as $L R=2\left|\ln L_{M S-G A R C H}-\ln L_{\text {GARCH }}\right|$ and Garcia tabulates the critical value for model with two regime shifts and Perron (1996) and Garcia (1998) based on the study of Davies (1987).

Table 2 reports that the LR test statistics are higher than the critical value for all markets. Hence, we can reject the null hypothesis of no regime change at a significance level of $1 \%$. However, it is clear that strategies 
Hedge fund are better described by a Markov Switching GARCH model compared to a GARCH $(1,1)$ with a single regime.

Table 3: MS-GARCH Results

\begin{tabular}{|c|c|c|c|c|c|c|}
\hline & $\mu\left(S_{t}=1\right)$ & $\mu\left(S_{t}=2\right)$ & $\sigma_{1}^{2}$ & $\sigma_{2}^{2}$ & $P_{11}$ & $\mathbf{P}_{22}$ \\
\hline \multicolumn{7}{|c|}{ Market Trend (Directional/Tactical) Index } \\
\hline Global Macro & $\begin{array}{c}0,416^{* * *} \\
(0,146)\end{array}$ & $\begin{array}{c}-0,158^{* * *} \\
(0,092)\end{array}$ & $\begin{array}{c}0,018 * * * \\
(0,001)\end{array}$ & $\begin{array}{c}0,0136^{* * * *} \\
(0,001)\end{array}$ & $\begin{array}{c}0,150^{* * *} \\
(0,001)\end{array}$ & $\begin{array}{c}0.125 \\
(0,116)\end{array}$ \\
\hline Emerging Markets & $\begin{array}{c}0.279 \\
(0.123)\end{array}$ & $\begin{array}{c}0,241 \\
(0.200)\end{array}$ & $\begin{array}{l}0.19^{* * * *} \\
(0.0001)\end{array}$ & $\begin{array}{c}0,0292 * * * \\
(0,001)\end{array}$ & $\begin{array}{l}0,014^{*} \\
(0.010)\end{array}$ & $\begin{array}{c}0.0123 * \\
(0,010)\end{array}$ \\
\hline Short Bias & $\begin{array}{c}0,032 \\
(0,188)\end{array}$ & $\begin{array}{c}0,175^{* * *} \\
(0,084)\end{array}$ & $\begin{array}{c}0,104 * * * \\
(0,016)\end{array}$ & $\begin{array}{c}0,035^{* * *} * \\
(0,002)\end{array}$ & $\begin{array}{c}0,918^{* * *} \\
(0,060)\end{array}$ & $\begin{array}{c}0,0164 \\
0,0121)\end{array}$ \\
\hline Equity hedge & $\begin{array}{c}0,713 \\
(0,180)\end{array}$ & $\begin{array}{c}-0,148 * * * \\
(0,086)\end{array}$ & $\begin{array}{c}0,030 \\
(0,003)\end{array}$ & $\begin{array}{l}0,0172 \\
(0,002) \\
\end{array}$ & $\begin{array}{c}0,452^{* * *} \\
(0,165)\end{array}$ & $\begin{array}{l}0,475^{*} \\
(0,269)\end{array}$ \\
\hline \multicolumn{7}{|l|}{ Arbitrage Index } \\
\hline Equity Market Neutral & $\begin{array}{c}0.119 * * * \\
(0.003)\end{array}$ & $\begin{array}{c}0,141 * * * \\
(0.001)\end{array}$ & $\begin{array}{c}0.052 * * * \\
(0.0013)\end{array}$ & $\begin{array}{c}0,0392 * * * \\
(0,0020)\end{array}$ & $\begin{array}{c}0,015^{*} \\
(0.011) \\
\end{array}$ & $\begin{array}{c}0.0122^{*} \\
(0,011) \\
\end{array}$ \\
\hline Convertible Arbitrage & $\begin{array}{c}0,909 * * * \\
(0,166)\end{array}$ & $\begin{array}{c}0,234 * * * \\
0,039)\end{array}$ & $\begin{array}{c}0,0326^{* * *} \\
0,004)\end{array}$ & $\begin{array}{c}0,008 * * * \\
0,0006)\end{array}$ & $\begin{array}{c}0,829 * * * \\
(0,093)\end{array}$ & $\begin{array}{c}0,056^{* * * *} \\
0,025)\end{array}$ \\
\hline Multi- Strategy & $\begin{array}{c}0,636^{* * * *} \\
(0,185)\end{array}$ & $\begin{array}{c}0,235^{* * * *} \\
(0,049)\end{array}$ & $\begin{array}{c}0,0152 * * * \\
(0,002)\end{array}$ & $\begin{array}{c}0,007 * * * \\
(0,0007)\end{array}$ & $\begin{array}{c}0,108 * * * \\
(0,096)\end{array}$ & $\begin{array}{c}0,501^{*} \\
(0,342)\end{array}$ \\
\hline \multicolumn{7}{|l|}{ Event Driven Index } \\
\hline Event Driven & $\begin{array}{c}0.881 * * * \\
(0.370)\end{array}$ & $\begin{array}{c}0.239 * * * \\
(0.064)\end{array}$ & $\begin{array}{c}0.026 * * * \\
(0.006)\end{array}$ & $\begin{array}{c}0.014 * * * \\
(0.001)\end{array}$ & $\begin{array}{l}0.284^{*} \\
(0.181) \\
\end{array}$ & $\begin{array}{c}0.082 \\
(0.064) \\
\end{array}$ \\
\hline Merger Arbitrage & $\begin{array}{c}0,003 \\
(0,004)\end{array}$ & $\begin{array}{c}0,0065^{* * * *} \\
(0,001)\end{array}$ & $\begin{array}{c}0,016^{* * * *} \\
(0,002)\end{array}$ & $\begin{array}{c}0,006^{* * * *} \\
(0,0008)\end{array}$ & $\begin{array}{l}0,501^{*} \\
(0,354)\end{array}$ & $\begin{array}{c}0,138 \\
0,105)\end{array}$ \\
\hline Fund of Funds & $\begin{array}{c}0,400 * * * \\
(0,125)\end{array}$ & $\begin{array}{c}0,265 * * * \\
(0,099)\end{array}$ & $\begin{array}{c}0,045^{* * * *} \\
(0,0028)\end{array}$ & $\begin{array}{c}0,0104 * * * \\
(0.0008)\end{array}$ & $\begin{array}{c}0,937 * * * \\
(0,0497)\end{array}$ & $\begin{array}{l}0,0315 \\
(0,022)\end{array}$ \\
\hline S\&P 500 & $\begin{array}{c}0.001 \\
(0.005)\end{array}$ & $\begin{array}{c}0.009 * * * \\
(0.003)\end{array}$ & $\begin{array}{c}0.058^{* * *} \\
(0.004)\end{array}$ & $\begin{array}{c}0.022 * * * \\
(0.002)\end{array}$ & $\begin{array}{c}0.980 * * * \\
(0.013)\end{array}$ & $\begin{array}{c}0.027 \\
(0.026)\end{array}$ \\
\hline
\end{tabular}

Note: Standard deviations are reported in parentheses. ${ }^{*}, * *$ and $* * *$ indicate that coefficients are significant at the $10 \%, 5 \%$ and $1 \%$ levels respectively.

Table 3 reports the estimates obtained by SW-GARCH process. At the first sight, we clearly observe the existence of two distinct regimes: the regime 1 corresponds to the high volatility state, and the regime 2 to the low volatility state. A close inspection of the estimates of variances shows that market volatility varies from 0.018 for Global Macro to 0.190 for Emerging Market.

Furthermore, the probability that a month of high volatility will be followed by a month of high volatility (i.e., the probability of staying in regime (1)) ranges from 0.015 for Equity Market Neutral to 0.937 for funds to funds. The probability of staying in low volatility regime is comprised between 0.012 for Equity Market Neutral and 0.501 for Multi-Strategies. Estimation results also indicate that the average return is positive and significant for to ten strategies hedge fund monthly returns during regime 1 (High volatility state) and ranges between 0.119 for Equity Market Neutral and $0.900 \%$ for Convertible Arbitrage. Besides, except those for Emerging Market, our results the average return is significant for all strategies hedge fund monthly returns during the regime of low volatility (-0.158 for Global Macro and 0.265 for Funds to Funds).

We then employ some specification tests to check the goodness-of-fit of the two-state MS- GARCH model as well as the robustness of the results.

In Table 4, J.B, P. (36) and ARCH (1) are the empirical statistics of the Jarque-Bera test for normality, Portmanteau test for autocorrelation in the standardized residuals and Engle (1982)'s test for conditional heteroscedasticity.

The null hypothesis of no ARCH effects cannot be rejected at conventional levels for four out of six cases (Convertible Arbitrage and SP500). With regard to the Portmanteau statistics, standardized residuals appear to be 
not serially autocorrelated (except Meger Arbitrage, Convertible Arbitrage and Multi-Strategy). Taken together, these tests show that the two-state Markov switching model explains satisfactorily the time-variations in monthly returns of sample strategies Hedge Fund index.
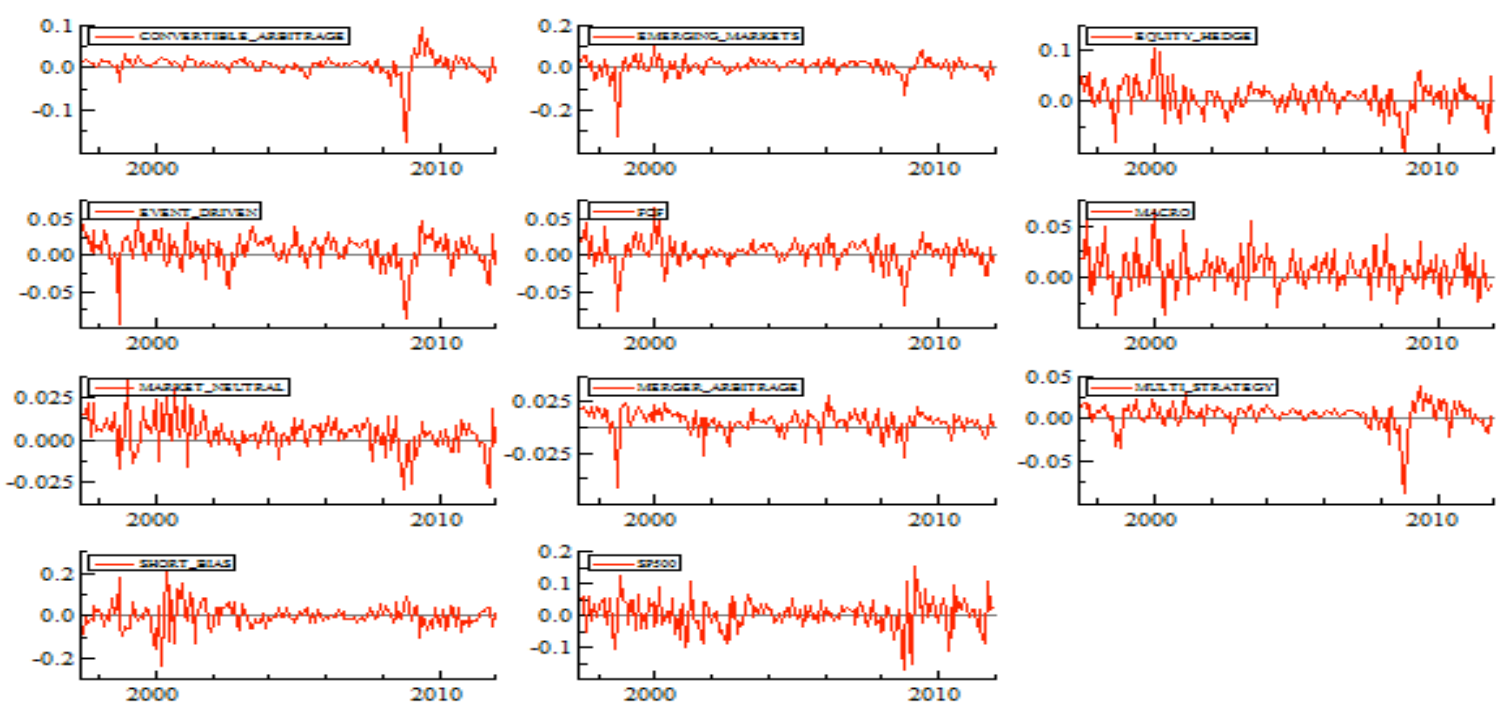

Figure 1: Hedge Funds Returns

Figure 2 plots the time-varying smoothed probabilities volatility state. A close look on these smoothed probabilities indicates that there is no common pattern in the regime shift dates among hedge fund monthly returns considered. The unique exception is around the year of 2008, when the smoothed probability of high volatility state increases for all hedge fund returns (expect Short Bias and Global Macro), thus reflecting the advent of the US subprime crisis followed by a global financial crisis. Other regime shifts tend to be coincided with several economic and political events occurring over the study period. We find a similar pattern in the regime shifts for the majority of hedge fund returns. For the Event Driven, Short Bias, Merger Arbitrage, Multi-strategies, and USA, the Turkish economic crisis, the Argentinean debt crisis that started in 2001 and 2002 marked the beginning of its first high volatility episode. Another high volatility regime is identified during the Russian and Brazilian financial crisis of 1998-1999. This finding indicates that the Equity Hedge Strategy, Equity Market Neutral, Funds to Funds, Short Bias and SP 500 are more likely to be affected by financial contagion and in crisis periods.

Figure 2: The Probability of Being in Regime 1 and 2

Emerging Market
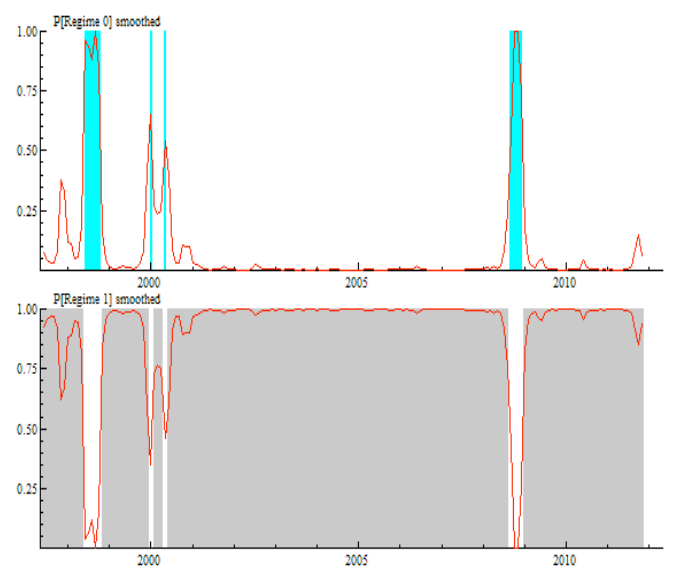

Equity Hedge Strategy
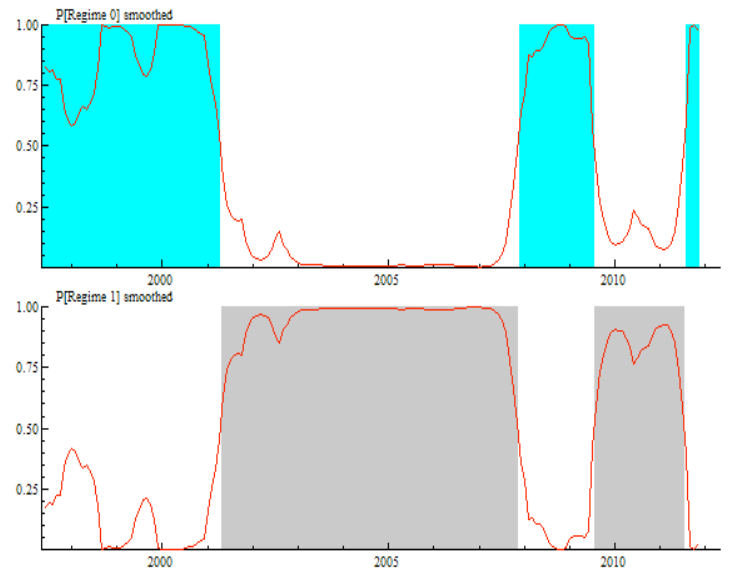

The Clute Institute 


\section{Figure 2 cont.}

Event Driven
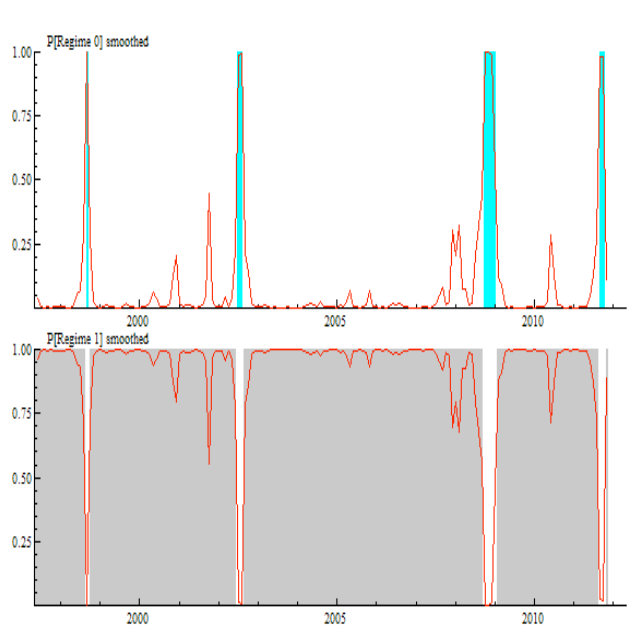

Fund of Fund
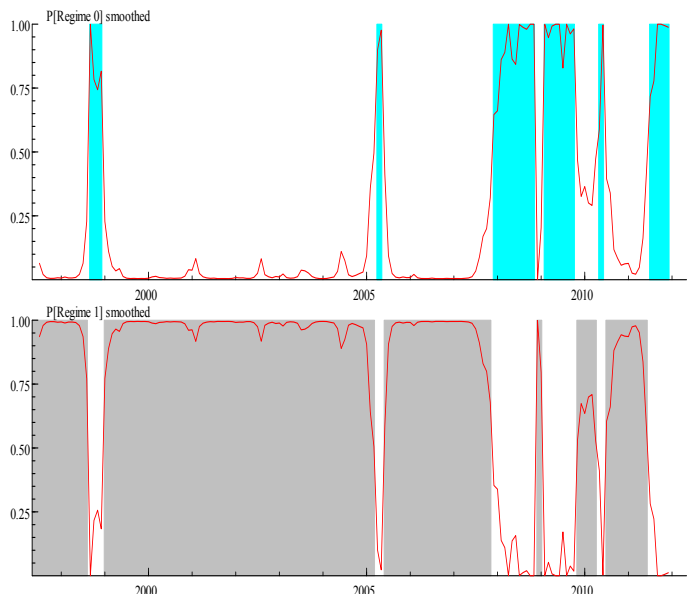

Short Bias
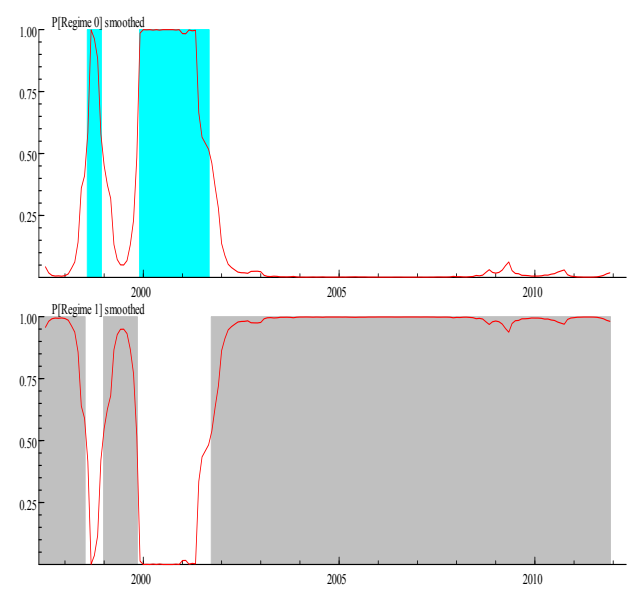

Copyright by author(s); CC-BY
Equity Market Neutral
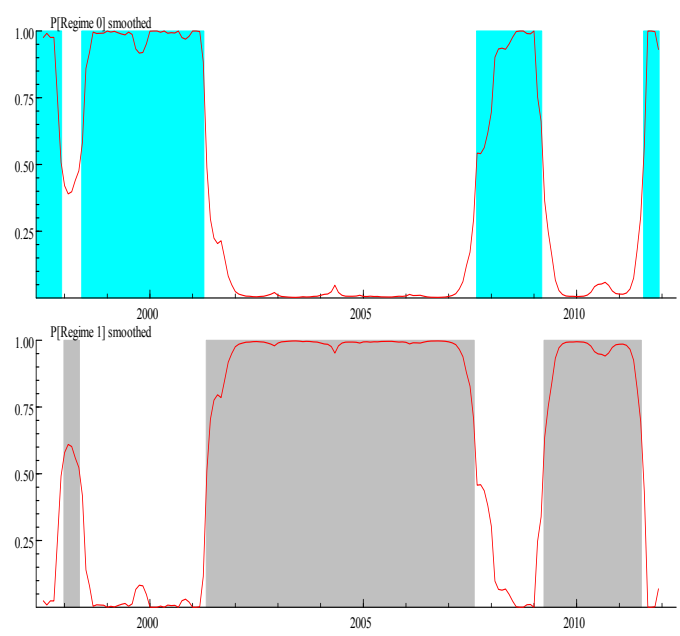

Convertible Arbitrage
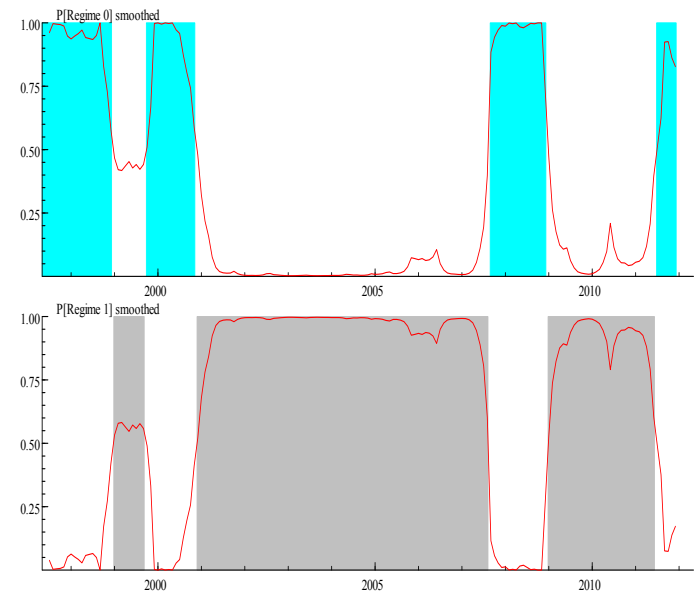

Global Macro

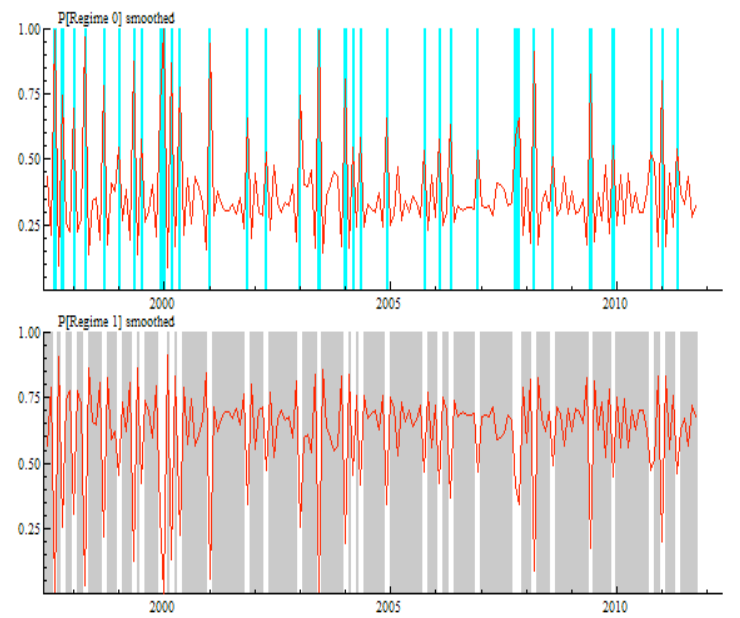


Figure 2 cont.

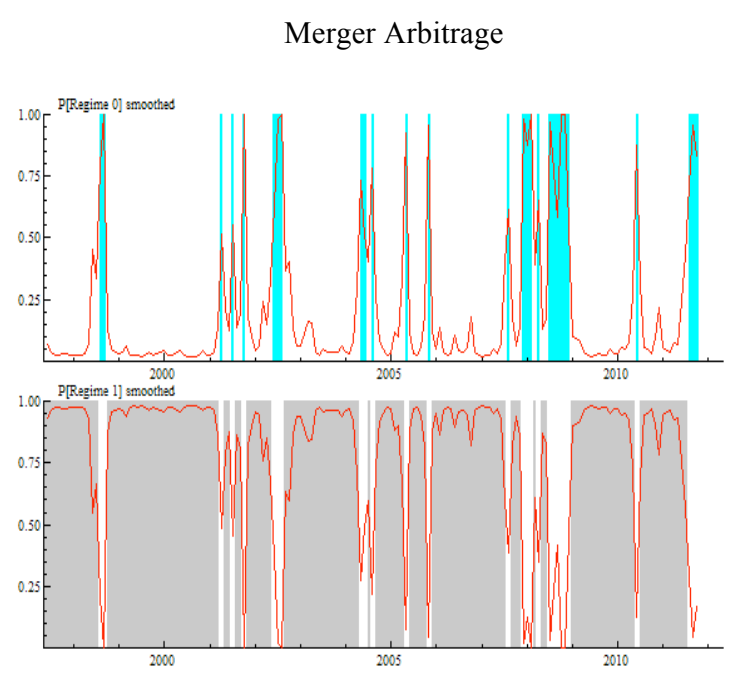

Merger Arbitrage
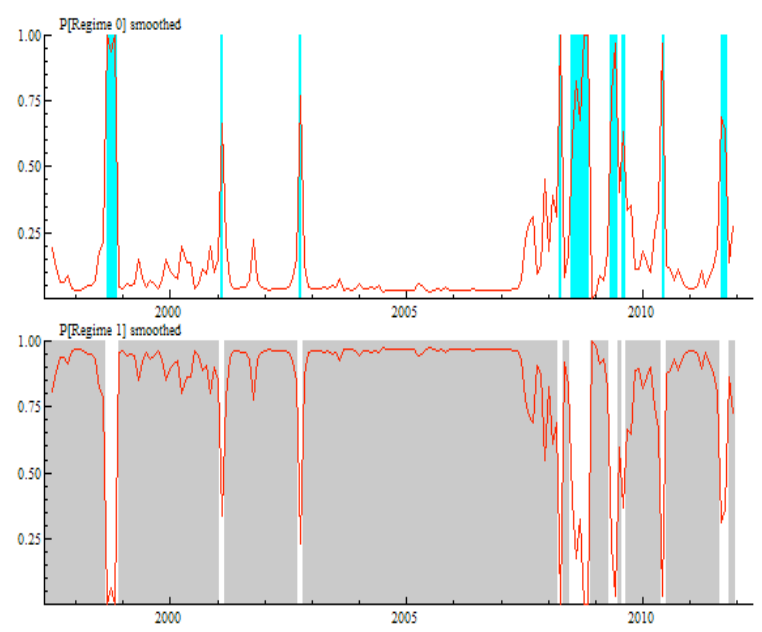

Multi-Strategy
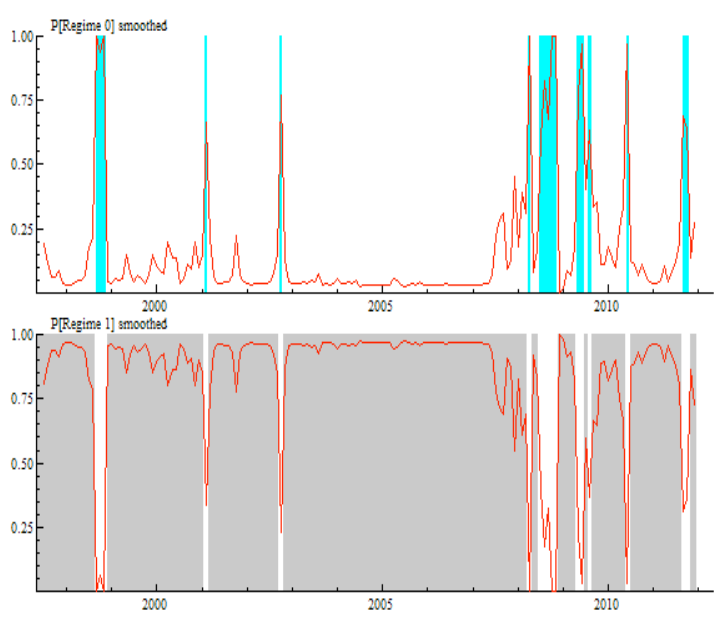

Multi-Strategy

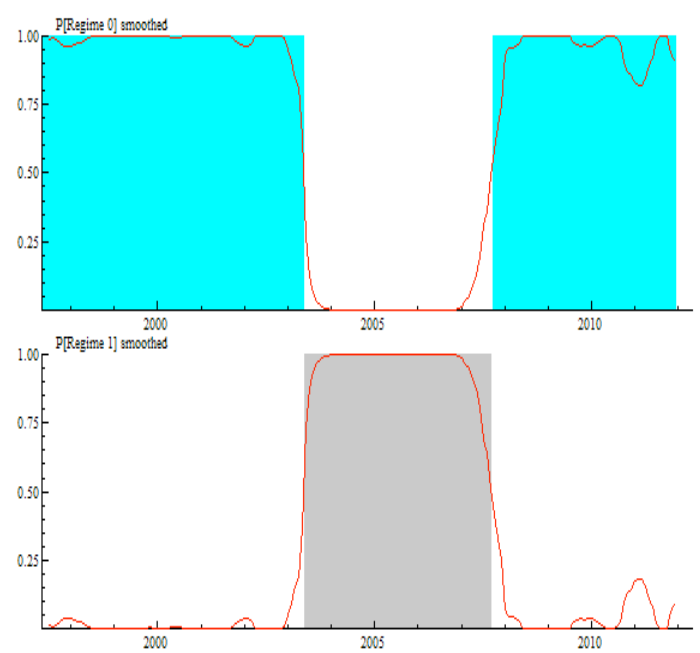

This empirical work aims to evaluate the contribution of hedge funds to the phenomenon of co-movement between financial assets and contagion in financial markets observed since the 1990s. In fact, alternative management strategies, diverse and dynamic, can be a channel for the transmission of shocks between markets. The dynamics of hedge funds portfolios led to a structure of risk exposure with the appearance of profiles and sequences characteristic likely to explain the co-movements between asset returns.

The period study is marked by four events market. The LTCM crisis of 1998, the crisis of the Internet bubble in 2000 and the subprime crisis in August 2007 and the global financial crisis of September 2008. The break of 2008 seems particularly marked with the subprime crisis and the collapse of Lehman Brothers.

\section{CONCLUSION}

The present study tried to study the volatility of ten strategies Hedge Fund index. We use the Markov regime shifts in order to study the behaviour of this strategies index. We find that hedge funds volatility is two regimes: the first regime with a negative average return with a very high volatility for all markets under study, the second regime with lower volatility and positive average returns. Our results helped to capture even the short-lived crises along with the material crises of 1998 and 2008. 


\section{AUTHOR INFORMATION}

Frédéric Teulon, IPAG Business School - IPAG Research Lab - Paris. E-mail: frederic.teulon@dbmail.com (Corresponding author)

Khaled Guesmi, IPAG Business School - IPAG Research Lab - Paris. EconomiX-CNRS, University of Paris Ouest Nanterre la Défense. E-mail: khaled.guesmi@ipag.fr

Saoussen Jebri, EconomiX-CNRS, University of Paris Ouest Nanterre la Défense. E-mail: saoussen_jebri@yahoo.fr

\section{REFERENCES}

1. Akaike, H. (1974). A new look at the statistical model identification. IEEE Transactions on Automatic Control, 19(6), 716-723.

2. Ang, A., \& Bekaert, G. (2002). Regime switches in interest rates. Journal of Business and Economic Statistics, 20(2), 163-182.

3. Ang, A., \& Chen, J. (2002). Asymmetric correlations of equity portfolios. Journal of Financial Economics, 63(3), 443-494.

4. Agarwal, V., \& Naik, N. (2004). Risks and portfolio decisions involving hedge funds. Review of Financial Studies, 17(1), 63-98.

5. Bollen, P., Gray, S.F., \& Whaley, R. (2000). Regime switching in foreign exchange rates: Evidence from currency option prices. Journal of Econometrics, 94, 239-276.

6. Cai, J. (1994). A Markov model of switching regime ARCH. Journal of Business and Economic Statistics, 12, 309-316.

7. Chauvet, M., \& Potter, S. (2000). Coincident and leading indicators of the stock market. Journal of Empirical Finance, 7(1), 87-111.

8. Chen Z., \& Forsyth, P.A. (2010). Implications of a regime-switching model on natural gas storage valuation and optimal operation. Quantitative Finance, 10, 159-176.

9. Dacco, R., \& Satchell, S. (1999). Why do regime-switching models forecast so badly?. Journal of Forecasting, 18(1), 1-16.

10. de Jong, C. (2006). The nature of power spikes: A regime-switch approach. Studies in Nonlinear Dynamics \& Econometrics, 10(3), Article 3.

11. Eling, M., \& Schumacher, F. (2007). Does the choice of performance influence the evaluation of hedge funds. Journal of Banking and Finance, 36, 2632-2647.

12. Engle, R. (1982). Autoregressive conditional heteroscedasticity with estimates of the variance of U.K. inflation. Econometrica, 50, 987-1008.

13. Engel, C., \& Hamilton, J. (1990). Long swings in the dollar: Are they in the data and do markets know it?. American Economic Review, 80(4), 689-713.

14. Engel, C. (1994). Can the Markov switching model forecast exchange rates? Journal of International Economics, 36, 151-165.

15. Fung, W., \& Hsieh, D. (1997). Empirical characteristics of dynamic trading strategies: the case of hedge funds. Review of Financial Studies, 10(2), 275-302.

16. Fung, W., \& Hsieh, D. (2011). The risk in hedge fund strategies: Theory and evidence from Long/Short Equity hedge funds. Journal of Empirical Finance, 18, 547-569.

17. Garcia, R., \& Perron, P. (1996). An analysis of the real interest rate under regime shifts. The Review of Economics and Statistics, 78(1), 111-125

18. Gray, S. (1996). Modeling the conditional distribution of interest rates as a regime-switching process. Journal of Financial Economics, 42, 27-62.

19. Hamilton, J. (1989). A new approach to the economic analysis of nonstationary time series and the business cycle. Econometrica, 57, 357-384.

20. Hannan, E., \& Quinn, J. (1979). The determination of the order of autoregression. Journal of the Royal Statistical Society, 41, 190-195. 
21. Hamilton, J. D., \& Susmel, R. (1994). Autoregressive conditional hetroscedasticity and changes in regime. Journal of Econometrics, 70, 127-157.

22. Wang, P., \& Theobald, M. (2008). Regime-switching volatility of six East Asian emerging markets. Research in International Business and Finance, 22(3), 267-283. 


\section{NOTES}

